\title{
Influence of Certain Insecticide Regimens Against Bollworms in Cotton Fields in Egypt
}

\author{
Ahmed F. El-Aswad ${ }^{1}$ and Hamdy K. Abou-Taleb ${ }^{2}$
}

\begin{abstract}
Comparative studies were carried out in five regimens to find out the best solution for cotton bollworm problems during cotton seasons of 2006 and 2007. These regimens were (1) of chlorpyrifos, chlorpyrifos, deltamethrin and deltamethrin. (2) of carbosulfan, spinosad, chlorpyrifos and deltamethrin. (3) of carbosulfan, carbosulfan, deltamethrin and deltamethrin. (4) of deltamethrin, chlorpyrifos, deltamethrin and carbosulfan. (5) of spinosad, chlorpyrifos, spinosad and carbosulfan. The sequence No. 5 achieved high efficacy against Pectinophora gossypiella which gave the reduction percentage of 87.6 and 88.1 while, the sequence No. 4 achieved superior efficacy against Earias insulana which gave 89.3 and 92.5 reduction of infestation throughout season 2006 and 2007, respectively. The statistical analysis decleared that regimen 4 and 5 were comparable, meanwhile they were significantly better than regimens 1,2 and 3 . The highest effective regimens 4 and 5 (gave about $87 \%$ infestation reduction) were started and mediated with pyrethroid compound (deltamethrin) and bioinsecticide (spinosad), respectively. The repetition of the same insecticide twice in a regimen might increase, decrease or has no effect on the insecticide efficiency against cotton bollworms.
\end{abstract}

Key words: Cotton bollworms, Pectinophora gossypiella, Earias insulana, Pesticide regimens.

\section{INTRODUCTION}

The most destructive bollworms that attack cotton in Egypt as well as in many countries are pink bollworm, Pectinophora gossypeilla (Saund.) and spiny bollworm, Earias insulana (Boisd.) (Ahmed et al., 2003 and ElAswad and Aly, 2007).

The protection of crop plants from different pests is one of the most important components of profitable farming system. Pest-controlling by chemical pesticides has an important role in management insect pests attacking crops, which can easily be applied, give rapid control and have been successful against insects. Furthermore, the insecticides are the only tool for pest management that is reliable for emergency action when insect pest populations approach or exceed the action threshold (Metcalf, 1982; Aydin and Gurken, 2006). Spinosad has strong insecticidal activity with low level of mammalian toxicity and relatively little toxicity to non-target insects (Sparks et al., 1998). Although spinosad is highly toxic to insect especially Lepidoptera insect pests, the resistance to spinosad increases rapidely in recent years (Wang et al., 2006).

The chemical control of bollworms $P$. gossypiella and $E$. insulana had been studied and the need of economic and wise use of chemicals against those insects induced many investigation objectives; efficiency of insecticides (Argentine et al., 2002 and ElAswad and Aly, 2007), different control treatments; sequential insecticides followed by pheromone and combination of pheromone and insecticides (Al-Beltagy et al., 1993), mixtures of different insecticides with IGRs or IDIs (Korkor et al., 1995), different spraying programmes and sequences of insecticides (Abo-ElGhar et al., 1973; El-Feel et al., 1991; Mourad et al., 1991 and Abou-Kahla et al., 1992) and timing of application and intervals of spray (Abdallah et al., 1980). Also, pyrethroid, carbamate and organophosphate insecticides are widely used on cotton for simultaneous control of the spiny bollworm $E$. insulana and the pink bollworm P. gossypiella (Shaaban et al., 1994 and Ahmed et al., 2003). In addition, El-Feel et al. (1991) assured the importance of using carbamate insecticides in the control of bollworms and that they should interrupt the sequence of organophosphates and pyrethroids. Therefore, pyrethroid insecticides can be applied as a part of a management program to control pink bollworm and spiny bollworm (El-Aswad and Aly, 2007). However, several studies have shown an increase in resistance of pink bollworm larvae due to pressure from intensive applications of pyrethroids (Bariola, 1985). The changes in toxicity among species of Lepidopterans exposed to the insecticides may be related to changes in rates of hydrolysis, as one pathway by which the insecticides are detoxified (Shaaban et al., 1994).

In addition to management of the resistance problem, the all mentioned instructions explored the aim of our study which is concentrated on the optimum regimen of insecticides from different groups gives high reduction in cotton bollworms infestation.

\section{MATERIALS AND METHODS}

\footnotetext{
${ }^{1}$ Pesticide Chemistry Dept., Faculty of Agriculture, Alexandria University

2 Plant Protection Research Institute, ARC, Bacous, Sabahia,

Alexandria, Egypt.

Received March1, 2008, Accepted March 29, 2008
} 


\section{Insecticides tested:}

- Chlorpyrifose; O,O-diethyl-O-(3.5.6-trichloro-2pyridyl) phosphoro-thioate. Chlorozan ${ }^{\circledR}$ (KZ Co.), $48 \% \mathrm{EC}$, at the rate of $1 \mathrm{~L} / \mathrm{Fed}$.

- Carbosulfan; 2,3-dihydro-2,2-dimethyl-7benzofuranyl[(dibutyl amino) thio] methyl carbamate. Marshal $^{\circledR}$ (Delta Co.), 25\% WP, at the rate of $600 \mathrm{~g} / \mathrm{Fed}$.

- Deltamethrin; (S)- $\alpha$-cyano-m-phenoxybenzyl (1R, 3R)3 (2,2-dibromo-vinyl)-2,2-dimethylcyclopropanecarboxylate. Dimethrin ${ }^{\circledR}$ (Agrochem), 2.5\% EC, at the rate of $750 \mathrm{ml} / \mathrm{Fed}$.

- Spinosad; it was a metabolite of the bacterium Saccharopolyspora spinosa and comprised of two macrocyclic lactones (spinosyns A and D); (2-[(6deoxy-2,3,4-tri-O-methyl- $\alpha$-L-mannopyranosyl)oxy]13-[(5-(dimethyl-amino)tetrahydro-6-methyl-2Hpyran-2-yl)oxy] -9-ethyl-2,3, 3a,5a,5b,6,9,10, 11,12, 13,14,16a,16b-tetradecahydro-14-methyl(D: 4,14dimethyl)-1H-as-indaceno (3, 2-d) oxacyclododecin7,15 -dione.Tracer ${ }^{\circledR} 24 \% \mathrm{SC}$, at the rate of 50 $\mathrm{ml} /$ Fed.

\section{Field trials:}

The experiments were conducted during the cotton growing seasons 2006 and 2007 in Alexandria University Experiment Station at Abees area. The cultivated cotton variety was Giza 70 . The average percent infestation in all experimental field plots was monitored till that reached $7 \%$ at zero time of application. Five treatments of insecticides regimens were applied. The treatments were regimen as follows: Regimen No. (1) of chlorpyrifos, chlorpyrifos, deltamethrin and deltamethrin. No. (2) of carbosulfan, spinosad, chlorpyrifos and deltamethrin. No. (3) of carbosulfan, carbosulfan, deltamethrin and deltamethrin. No. (4) of deltamethrin, chlorpyrifos, deltamethrin and carbosulfan. No. (5) of spinosad, chlorpyrifos, spinosad and carbosulfan. Plots of $1 / 100$ feddan $\left(42 \mathrm{~m}^{2}\right)$ each arranged in randomized design. Four replicates were sprayed four times (every two weeks) using a knapsack sprayer at the rate of 400 liter per feddan.

\section{Laboratory examination:}

For each treatment, samples of 25 green bolls were collected at random from both diagonals of each replicate (100 green bolls/treatment) before spraying time and weekly after insecticide application. Percentage of infestation by pink bollworm, $P$. gossypiella and that of spiny bollworm, E. insulana were determined in the laboratory by dissection of bolls and checking the bolls externally and internally. The percent reduction of pink bollworm or spiny bollworm infestation was calculated according to Henderson and Tilton (1955).

\section{Statistical analysis:}

The treatments were compared with each other using one way ANOVA with LSD test according to Costat statistical software (1990).

\section{RESULTS AND DISCUSSION}

The use of insecticides is one of the most important means of controlling cotton pests, especially the cotton bollworms Pectinophora gossypiella and Earias insulana, which spend most of their life-cycles inside the bolls. Therefore, the use of insecticides against these two insect pests takes place to keep the level of the infestation under the economic threshold.

Field performance of tested different sequences of insecticides against Pectinophora gossypiella during two seasons

Five insecticidal sequences were evaluated and represented by four different insecticides; chlorpyrifos (organophosphorus), carbosulfan (carbamate), deltamethrin (pyrethroide) and spinosad (bioinsecticide). The exhibited data in Table (1) demonstrate the calculated reduction percentages of the pink bollworm, Pectinophora gossypiella during the application of five suggested sequences of certain insecticides. The first spray by carbosulfan in regimen 1 and 2 caused infestation reduction percentage of 87.4 and 88.3 during season 2006 and 87.3 and 89.9 during season 2007, respectively. The percentages of infestation reduction of all tested insecticides were more in the first week after treatment than that in the second week throughout the four sprays. All tested compounds in the different regimens reduced the infestation of $P$. gossypiella, the infestation reduction percentages were more than $81.0 \%$ during the two seasons. Regarding to the second spray, the application of chlorpyrifos after deltamethrin caused 91.9 and $89.3 \%$, while after spinosad caused 92.2 and $91.7 \%$ reduction of infestation for both seasons 2006 and 2007, respectively. The statistical analysis indicated that the regimen 4 and 5 achieved the highest reduction percentages during the $3^{\text {rd }}$ spray in contrast, the regimen 1 and 2 achieved low efficacy during the $4^{\text {th }}$ spray application. The sequence No. 5 (spinosad, chloropyrifos, spinosad and carbosulfan), Sequence No. 4 (deltamethrin, chlorpyrifos, deltamethrin and carbosulfan) achieved high efficacy during the $1^{\text {st }}, 2^{\text {nd }}, 3^{\text {rd }}$ and $4^{\text {th }}$ spray applications, which gave the following reduction percentages of (89.6 and 81.7), (92.2 and 91.9), (82.1 and 81.4) and (86.4 and 84.2) during season 2006 and (91.8 and 84.7), (91.7 and 89.3), (81.4 and 78.7) and (87.7 and 82.8) during season 2007, respectively. The 
data also revealed that the efficiency of sequence No. 3 (carbosulfan, carbosulfan, deltamethrin and deltamethrin) took a middle site between treatments. In addition, the sequence No. 2 which has four different insecticides (carbosulfan, spinosad, chlorpyrifos and deltamethrin) depress the efficiency of that sequence against the pink bollworm, $P$. gossypiella.

Also, the statistical analysis revealed that there were significant differences among tested regimens. While regimen 5 was the best and significantly showed good reduction in boll infestation during both seasons 2006 and 2007 , followed by regimen 4 . The lowest efficacy was obtained from regimen 2 , followed by regimen 1 during the two seasons. According to significant differences, the data clearly show that the starting and mediating the sequence with spinosad (regimen 5) induced the efficiency of that sequence against pink bollworm. Also, the starting and mediating the sequence with deltamethrin (regimen 4) gave high infestation reduction percentage compared to other tested regimens. These results are in agreement with El-Gogary (1987), who reported that starting the programme with organosphosphate followed by pyrethroids gave less satisfactory results. In contrast, El-Feel et al. (1993) mentioned that pyrethroids could not be able to reduce the building-up of the bollworm population at the early season. While at the late season this aim is not considered.

\section{Field performance of tested different sequences of insecticides against Earias insulana during two seasons}

The elucidated data in Table (2) show the variation between the weekly calculated reduction of the infestation percentages by the spiny bollworm when different sequences of insecticides were used. Concerning the first spray application during both seasons 2006 and 2007, the statistical significant difference in infestation reduction percentages was found between all applied insecticides on a hand and on the other hand chlorpyrifos which gave the lowest values. The sequence No. 4 (deltamethrin, chlorpyrifos, deltamethrin and carbosulfan) achieved superior efficacy during the $1^{\text {st }}, 2^{\text {nd }}, 3^{\text {rd }}$ and $4^{\text {th }}$ spray applications, where it resulted in (89.6, 95.3, 84.4 and 88.1) and (93.8, 94.3, 89.6 and 92.5) throughout the seasons 2006 and 2007, respectively. The results indicated that the repetition of the same insecticide twice in a regimen did not showed a clear effect could be increase, decrease or no effect on the insecticide efficiency. Therefore, the application of chlorpyrifos in the $2^{\text {nd }}$ spray after the same treatment in the $1^{\text {st }}$ spray within regiment 1 improved the insecticide efficiency against the spiny bollworm, where the infestation reduction increased from 61.1 to $86.5 \%$ during season 2006 and from 62.2 to $87.2 \%$ during season 2007 . While, the repetition of carbosulfan within regimen 3 for $1^{\text {st }}$ and $2^{\text {nd }}$ spray applications depress the insecticide efficiency, the infestation reduction decreased from 86.3 to $75.2 \%$ and from 90.6 to $75.0 \%$ during the two seasons 2006 and 2007, respectively. Moreover, almost no effect of infestation reduction percentage was recorded by repetition of deltamethrin application.

According to the statistical analysis of the general mean reduction percentages, the sequence of deltamethrin, chlorpyrifos, deltamethrin and carbosulfan (sequence regime 4) came first (89.3 and 92.5\%) during season 2006 and 2007, respectively. El-Feel et al. (1991), Mourad et al. (1991) and Abou-Kahla et al. (1992) reported that starting the controlling programme with synthetic pyrethroids induced the highest reduction of the bollworms infestation. No significant difference was recorded between regimen 2 (carbosulfan, spinosad, chlorpyrifos and deltamethrin) and regimen 5 (spinosad, chlorpyrifos, spinosad and carbosulfan). Both regimens ( 2 and 5) came in the second order ( 83.6 and $84.9 \%$ ) and $(88.6$ and $87.6 \%)$ during season 2006 and season 2007, respectively. The sequence No. 3 took a middle site between tested sequence, it came in the third order 81.6\% during season 2006 and 84.6\% during season 2007. However, the fourth order was for the sequence regimen 1 (chlorpyrifos, chlorpyrifos, deltamethrin and deltamethrin) which gave 77.6 and $79.8 \%$ reduction of infestation for season 2006 and season 2007, respectively.

\section{Field performance of tested different sequences of insecticides against cotton bollworms}

To know the effect of different regimens on the both bollworms $P$. gossypiella and E. insulana together. The infestation reduction of bollworms was calculated and their values presented in Table (3). The lowest percentage of infestation reduction was obtained by regimen 1 during $1^{\text {st }}$ spray. The repetition application of chlorpyrifos in the $2^{\text {nd }}$ spray increased the infestation reduction while, the repetition of carbosulfan (regimen 2) decreased the infestation reduction during the two seasons. Significant differences were detected between regimen 2 and other tested regimens except regimen 3. Regarding to the general mean, all tested sequences caused the infestation reduction percentages more than $78 \%$ throughout the two seasons. However, both regimens 4 and 5 were significantly higher in infestation reduction than that of other regimens. Consequently, the statistical analysis indicated that the regimen 1 was the lowest efficacy.

The average of infestation reduction percentages of bollworms was also estimated (Table 4) for the two seasons. The data indicated that the regimen 5 showed superior reduction in $P$. gossypiella $(87.9 \%$ infestation reduction) followed by regimen $4(84.4 \%)$. 
Table 3. Infestation reduction percentage of cotton bollworms during two seasons (2006 and 2007)

\begin{tabular}{|c|c|c|c|c|c|}
\hline \multirow{2}{*}{ Treatments } & \multicolumn{4}{|c|}{ Infestation reduction \% of four sprays } & \multirow{2}{*}{ General mean } \\
\hline & 1 & 2 & 3 & 4 & \\
\hline & \multicolumn{5}{|c|}{ Season 2006} \\
\hline \multirow{2}{*}{ Regimen 1} & Chlorpyrifos & Chlorpyrifos & Deltamethrin & Deltamethrin & \\
\hline & $71.6 \mathrm{~b}$ & $85.0 \mathrm{~b}$ & $79.4 \mathrm{ab}$ & $79.2 \mathrm{~b}$ & $78.8 \mathrm{c}$ \\
\hline \multirow{2}{*}{ Regimen 2} & Carbosulfan & Spinosad & Chlorpyrifos & Deltamethrin & \\
\hline & $87.3 \mathrm{a}$ & $84.8 \mathrm{~b}$ & $76.8 \mathrm{~b}$ & $75.0 \mathrm{c}$ & $81.0 \mathrm{~b}$ \\
\hline \multirow{2}{*}{ Regimen 3} & Carbosulfan & Carbosulfan & Deltamethrin & Deltamethrin & \\
\hline & $87.3 \mathrm{a}$ & $75.6 \mathrm{c}$ & $79.6 \mathrm{ab}$ & $83.5 \mathrm{a}$ & $81.5 \mathrm{~b}$ \\
\hline \multirow{2}{*}{ Regimen 4} & Deltamethrin & Chlorpyrifos & Deltamethrin & Carbosulfan & \\
\hline & $85.6 \mathrm{a}$ & $93.6 \mathrm{a}$ & $82.9 \mathrm{a}$ & $86.2 \mathrm{a}$ & $87.1 \mathrm{a}$ \\
\hline \multirow{2}{*}{ Regimen 5} & Spinosad & Chlorpyrifos & Spinosad & Carbosulfan & \\
\hline & $87.3 \mathrm{a}$ & $92.0 \mathrm{a}$ & $79.9 \mathrm{ab}$ & $85.7 \mathrm{a}$ & $86.3 \mathrm{a}$ \\
\hline \multirow[t]{2}{*}{$\operatorname{LSD}_{0.5}$} & 2.587 & 3.170 & 3.023 & 3.077 & 1.098 \\
\hline & \multicolumn{5}{|c|}{ Season 2007} \\
\hline \multirow{2}{*}{ Regimen 1} & Chlorpyrifos & Chlorpyrifos & Deltamethrin & Deltamethrin & \\
\hline & $74.3 \mathrm{~b}$ & $83.5 \mathrm{~b}$ & $79.9 \mathrm{ab}$ & $79.6 \mathrm{c}$ & $79.3 \mathrm{c}$ \\
\hline \multirow{2}{*}{ Regimen 2} & Carbosulfan & Spinosad & Chlorpyrifos & Deltamethrin & \\
\hline & $89.3 \mathrm{a}$ & $81.9 \mathrm{~b}$ & $78.6 \mathrm{~b}$ & $83.7 \mathrm{~b}$ & $83.4 \mathrm{~b}$ \\
\hline \multirow{2}{*}{ Regimen 3} & Carbosulfan & Carbosulfan & Deltamethrin & Deltamethrin & \\
\hline & $90.3 \mathrm{a}$ & $75.2 \mathrm{c}$ & $84.8 \mathrm{a}$ & $80.7 \mathrm{c}$ & $82.8 \mathrm{~b}$ \\
\hline \multirow{2}{*}{ Regimen 4} & Deltamethrin & Chlorpyrifos & Deltamethrin & Carbosulfan & \\
\hline & $89.2 \mathrm{a}$ & $91.8 \mathrm{a}$ & $84.2 \mathrm{a}$ & $87.7 \mathrm{a}$ & $88.2 \mathrm{a}$ \\
\hline \multirow{2}{*}{ Regimen 5} & Spinosad & Chlorpyrifos & Spinosad & Carbosulfan & \\
\hline & $91.9 \mathrm{a}$ & $91.3 \mathrm{a}$ & $81.5 \mathrm{ab}$ & $86.9 \mathrm{a}$ & $87.9 \mathrm{a}$ \\
\hline LSD $_{0.5}$ & 2.079 & 2.771 & 3.984 & 2.233 & 0.876 \\
\hline
\end{tabular}

Values within the same column having the different letters are significantly different according to Student-Newman Keuls test at P=0.05 level

on the other hand, regimen 1 and 2 were the least effective tested insecticide sequences in this respect. Feshawi et al. (1991) evaluated the efficiency of different insecticides as a program of cyfluthrindeltamethrin-profenos-thiodicarb or profenofosthiodicarb-deltamethrin-profenofos, they found that such sequences induced high reduction in the larval population of $P$. gossypiella. For Earias insulana, there was no significant differences among all tested insecticide regimens except regimen 1 which was lowest efficacy $(78.7 \%)$. This finding is in agreement with those of Tadros (2003) who showed that the starting of insecticide sequence by organophosphorus compound, chlorpyrifos gave reduction of E. insulana infestation $(71.4 \%)$.

The average of infestation reduction for both bollworms $P$. gossypiella and E. insulana and the average values for the two seasons 2006 and 2007 was summarized in Table (4) as an infestation reduction of cotton bollworms. Using statistical analysis, the tested different insecticide sequences could be grouped in two groups as follows; First group, which included the regimens that gave about $87 \%$ reduction namely regimen 4 and regimen 5. Second group, which included regimen 1, regimen 2 and regimen 3 which gave 79.1 to $82.2 \%$ reduction. This finding is in accordance with that reported by Tadros (2003) who reported that the different modes of action of tested compounds allow these compounds to reduce the bollworms infestation initially and for long period. It was observed that the high effective regimen No. 4 was started and mediated with pyrethroid compound, deltamethrin. This result could be explained as the pyrethroid compound has a high quick-contact effect which resulted in a few survival insect pests in their first generation. This finding was supported by Duhoon and Banerjee (1984) who reported that synthetic pyrethroids gave good results followed by organophosphorus compounds against the pink bollworm $P$. gossypiella. Also, these results are in agreement with findings of Gupta (1990) 
Table 4. Average of infestation reduction percentage for bollworms in 2006 and 2007 cotton seasons

\begin{tabular}{cccc}
\hline Treatments & Pectinophora gossypiella & Earias insulana & Cotton bollworms \\
\hline Regimen 1 & $79.4 \mathrm{~d}$ & $78.7 \mathrm{~b}$ & $79.1 \mathrm{~b}$ \\
Regimen 2 & $78.3 \mathrm{~d}$ & $86.1 \mathrm{ab}$ & $82.2 \mathrm{~b}$ \\
Regimen 3 & $81.2 \mathrm{c}$ & $83.1 \mathrm{ab}$ & $82.2 \mathrm{~b}$ \\
Regimen 4 & $84.4 \mathrm{~b}$ & $90.9 \mathrm{a}$ & $87.7 \mathrm{a}$ \\
Regimen 5 & $87.9 \mathrm{a}$ & $86.3 \mathrm{ab}$ & $87.1 \mathrm{a}$ \\
\hline LSD $_{\mathbf{0 . 5}}$ & 1.358 & 6.080 & 2.753 \\
\hline Values within the same column having the different letters are significantly different according to Student-Newman Keuls test at P=0.05 level
\end{tabular}

who noticed that the synthetic pyrithroids gave highly effective reduction of the infestation of bollworms. In addition, Khidr et al. (1996) found that pyrethroids gave high degree of control when they were used against the cotton bollworms. Furthermore, El-Aswad and Aly (2007) concluded that the tested pyrethroid, deltamethrin was more effective in reducing cotton bollworm infestation than that of the tested organophosphorus insecticide, chlorpyrifos. In similar, the high effective regimen No. 5 was started and mediated with bioinsecticide, spinosad. Similar results were elucidated by Tadros (2003) who reported that Achook as a botanical insecticide resembles the efficiency of the used synthetic insecticides showing a promisable way in the control programme of both cotton bollworms. Also, Mohan and Katiyar (2000) declared that the spray schedule containing botanical insecticide proved to be superior in controlling bollworms compared with those schedules based only on the conventional insecticides.

\section{Conclusion}

In general, the afore-mentioned results, either in the pink bollworm or spiny bollworm, demonstrate that similar effect was obtained when such sequences were applied. According to the average of infestation reduction for both bollworms $P$. gossypiella and $E$. insulana and for the two seasons 2006 and 2007, the tested different insecticide sequences could be grouped in two groups as follows; First group included the regimen 4 and regimen 5 that gave about $87 \%$ infestation reduction. Second group included the other tested regimens, gave 79.1 to $82.2 \%$ infestation reduction. The high effective regimens (4 and 5) were started and mediated with pyrethroid compound (deltamethrin) and bioinsecticide (spinosad), respectively. In general, this study point out to minimize repetition of insecticide application in the same season, furthermore using bioinsecticide in sequence with synthetic insecticides and looking forward to an integrated pest management to overcome pest problems.

\section{REFERENCES}

Abdallah, S. A.; E. I. El-Sayed and M. Nagi (1980). Timing of insecticidal application for control of the pink bollworm. Proc. $1^{\text {st }}$ Conf., Pl. Prot. Res. Ins., 1:47-56.

Abo El-Ghar, M. R.; H. S. A. Radwan and I. A. El-Keie (1973). Effect of different spraying programmes on the pink bollworm, Pectinophora gossypiella (Saund) infestation and yield of cotton. Bull. Ent. Soc. Egypt. Econ. Ser., 9:203-210.

Abou-Kahla, M. M.; A. E. M. El-Sorady; R. M. Salem and A. M. Hussain (1992). Impact of several sequences of insecticides against certain cotton pests and the associated predators in cotton fields. J. Agric. Res. Tanta Univ., 18 (4): 802-817.

Ahmad, M.; M. I. Arif and Z. Ahmad (2003). Susceptibility of Heliocoverpa armigera (Lepidoptera: Noctuidae) to new chemistries in Pakistan. Crop Protection 22: 539-544.

Al-Beltagy, A. M.; M. S. Shawir; K. A. Osman; M. M. AboElsaad and M. A. Mourad (1993). Biochemical techniques for measuring susceptibility of pink bollworms, Pectinophora gossypiella to certain insecticides. Alex. J. Agric. Res., 38 (3):393-411.

Argentine, J. A.; R. K. Jansson; W. R. Halliday; D. Rugg and C. S. Jany (2002). Potency, spectrum and residual activity of four new insecticides under glasshouse conditions. Florida Entomologist, 85(4): 552-562.

Aydin, H. and M. O. Gürkan (2006). The efficacy of spinosad on different strains of Spodoptera littoralis (Boisduval) (Lepidoptera: Noctuidae). Turk J. Biol., 30, 5-9.

Bariola, L. A. (1985). Evidence of resistance to synthetic pyrethroids in the field populations of pink bollworm in southern California. In: Proc. to the belt cotton production and research Conf., Jan 6-11, New Orleans, LA.

CoStat Statistical Software (1990). Microcomputer program analysis Version 4.20, CoHort Software, Berkeley, CA.

Duhoon, S. S. and S. K. Banerjee (1984). Efficacy of some synthetic pyrethroids for the control of bollworms in desi cotton (Gossyphum arboretum Linn) India, J. Ent., 46 (2):122-125. 
El-Aswad, A. F. and M. I. Aly (2007). Screening of some insecticides against the cotton bollworms, Pectinophora gossypiella (Saund. ) and Earias insulana (Boisd.). J. Pest Cont. \& Environ. Sci., 15 (2):63-74.

El-Feel, E. A.; A. A. Khidr; M. M. Abou-Kahla and M. G. Abbass (1991). Effect of insecticidal sequence, time intervals between sprays and early spray on the pink bollworm, Pectinophora gossypiella (Saund.) and cotton yield. Egypt. J. Agric. Res., 69 (1):73-82.

El-Feel, E. A.; A. E. M. El-Sorady; H. A. Awad and M. E. Omar (1993). Influence of certain insecticide regimens against bollworms and other cotton pests and their predators. Alex. Sci. Exch., 14 (1):145-165.

El-Gogary, O. A. (1987). Effect of phermones and chemical pesticides on population density of cotton bollworms. Ph.D. Thesis, Fac. Agric., Helwan Univ.

Feshawi, A. A.; M. W. Guirguis; M. W. Watson and M. A. Nassef (1991). Studies on the pink bollworm, Pectinophora gossypiella (Saund. ). II. Chemical control programs for the cotton pink bollworm. Egypt. J. Agric. Res., 69 (1):89-95.

Gupta, G. P. (1990). Chemical control of bollworms synchronized with flowering in cotton. J. Ent. Res., 14 (2):146-149.

Henderson, C. F. and F. W. Tilton (1955). Test with acaricides against the brown wheat mite. J. Econ. Entomol., 48:157161.

Khidr, A. A.; G. M. Moawad; W. M. H. Desuky; A. A. ElSheakh and S. A. Raslan (1996). Effect of some synthetic pyrethroids on bollworms larvae in cotton fields. Egypt. J. Agric. Res., 74 (1):123-132.

Korkor, A. A.; M. Z. F. Awad; A. M. Hamid and M. B. AboSalem (1995). Screening of some insecticides against bollworms and whitefly attacking cotton plants. Com. In Sci. and Dev. Res., 745 (50):141-157.

Metcalf, R. L. (1982). Insecticides in pest management. By: Metcalf R.L. and Luckmann W.H. (eds.). In: Introduction to the insect pest management ( $2^{\text {nd }}$ ed.). New York, 217278.

Mohan, M. and K. N. Katiyar (2000). Effect of insecticides on the population and incidence of bollworms in cotton. Shashpa., 7 (2):171-175.

Mourad, M. A.; M. E. Omar and A. A. Mahran (1991). Alternate use of insecticides against the cotton bollworms Pectinophora gossypiella (Saund. ) and Earias insulana (Boisd.). J. Agric. Res., 69 (1):99-106.

Shaaban, Z.; M. Morshedy and N. A. Mansour (1994). Enzyme activities and inhibitions versus insecticide toxicities in Pectinophora gossypiella, Earias insulana and Spodoptera littoralis. Com. In Sci. and Dev. Res., 690 (45):197-211.

Sparks, T. C.; G. D. Thompson; H. A. Kirst; M. B. Hertlein; L. L. Larson; T. V. Worden and S. T. Thibault (1998). Biological activity of the spinosyns, new fermentation derived insect control agents, on tobacco budworm (Lepidoptera: Noctuidae) larvae. J. Econ. Entomol., 91:1277-1283.

Tadros, H. M. (2003). Effect of some insecticides on cotton bollworms and on quantity and quality of cotton yield. M.Sc., Fac. of Agric. (Saba-Bacha), Alex. Univ., Alexandria, Egypt.

Wang, W.; J. Mo; J. Cheng; P. Zhuang and Z. Tang (2006). Selection and characterization of spinosad resistance in Spodoptera exigua (Hubner) (Lepidoptera: Noctuidae). Pesticide Biochem. and Physiol., 84:180-187. 


\section{الملخص العربي}

\section{دراسة تأثير تطبيق بعض نظم تتابع المبيدات الحشرية ضد ديدان اللوز فى حقول القطن فى مصر}

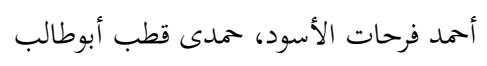

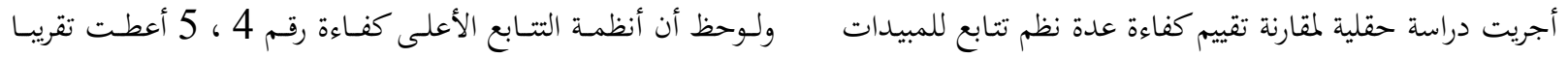

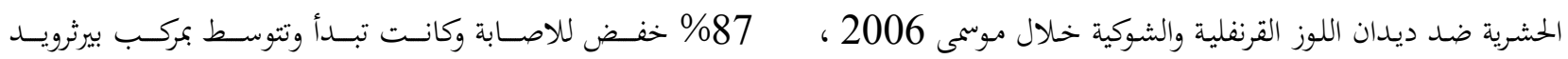

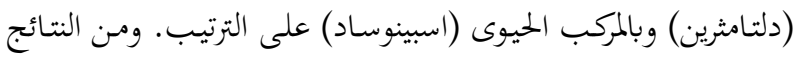
2007. وكانت أنظمة التتابع المختبرة هى:

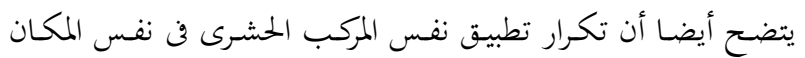

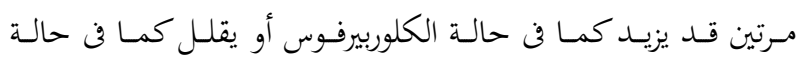
1 - كلوربيرفوس - كلوربيرفوس - دلتامثرين - دلتامثرين.

الكربوسلفان أو لايؤثر كما في حالة الدلتامثرين على كفـاءة المركب المبان 2- كربوسلفان - اسبينوساد - كلوربيرفوس - دلتامثرين. 3- كربوسلفان - كربوسلفان - دلتامثرين - دلتامثرين.

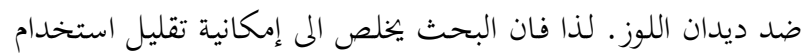
4- دلتامثرين - كلوربيرفوس - دلتامثرين - كربوسلفان.

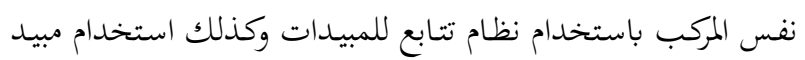
5- اسبينوساد - كلوربيرفوس - اسبينوساد - كربوسلفان.

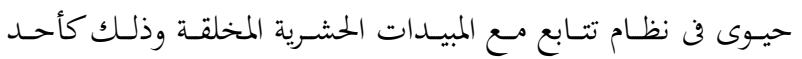
ابتحات المكافحة المتكاملة لديدان اللوز فن القطن.

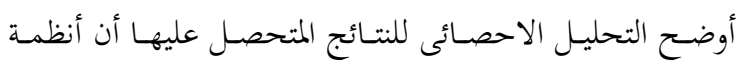

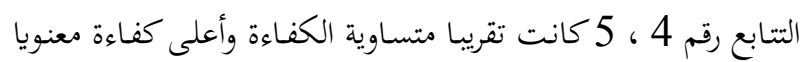
عن بقية الأنظمة المختبرة رقم 1 ، 2 ، 3. 